\title{
Limits to Microbial Growth in Soil
}

\author{
By J. M. LYNCH \\ Agricultural Research Council Letcombe Laboratory, Wantage, Oxon OX12 9JT, U.K.
}

(Received 7 April 1981; revised 9 June 1981)

\begin{abstract}
More organic carbon was released into solution from soils that had been air-dried and rewetted than from the natural soils. Irradiation and autoclaving of a range of air-dried or field soils greatly increased the amount of carbon that was released into solution. The carbon released appeared to provide substrates for fungal spore germination and bacterial growth, thereby relieving microbiostasis. The percentage germination of Penicillium citrinum spores was at least doubled in sterilized soil and halved in untreated soil compared with spores germinating in the absence of soil. In general, a streptomycin-resistant strain of Agrobacterium radiobacter made significant growth only in sterilized soils.
\end{abstract}

\section{INTRODUCTION}

The germination and growth of fungi in natural soils are much more restricted than would be expected from their behaviour under similar conditions of temperature, moisture and $\mathrm{pH}$ in vitro. This generalization was first formulated by Dobbs \& Hinson (1953) and the evidence for it was reviewed by Lockwood (1977). Demonstration of fungistasis has usually been by measuring percentage spore germination after incubation on agar discs placed on soil compared with that on filter paper. Sterilization of the soil alleviates the inhibition.

Two possible explanations, which are not necessarily mutually exclusive, are the presence of toxins in the soil or an inadequate nutrient supply. Many investigators have shown that the putative toxins are volatile and include ammonia in alkaline soils (Ko et al., 1974; Schippers \& Palm, 1973). The proposal that ethylene formation in anaerobic soils was a general explanation for fungistasis (Smith \& Cook, 1975) has not been substantiated (Drew \& Lynch, 1980). In a soil from Hawaii, Ko \& Hora (1972) found that an Al ion was fungitoxic. However, the failure to find a non-specific fungistatic agent and the similarity in behaviour of propagules incubated on soil and in various model systems that impose nutrient-deprived environments lends support to the nutrient deprivation hypothesis (Lockwood, 1977). Fungistasis can often be counteracted by the addition of nutrients to soils, but the evidence is still somewhat indirect.

Soil bacteriostasis has been demonstrated in a similar way to fungistasis, but the diameters of bacterial colonies were measured instead of spore germination (Brown, 1973; Davis, 1975). Such measurements are inexact and, more recently, Ko \& Chow (1977) demonstrated the phenomenon by adding streptomycin-resistant bacteria to soils and counting them immediately after addition and $24 \mathrm{~h}$ later. Bacterial growth could not be detected except when the soil was autoclaved or when glucose and peptone were added. They reported an increase in Agrobacterium radiobacter populations from $5 \times 10^{6}$ to $3 \times 10^{16}$ bacteria (g dry soil) $)^{-1}$ but this was misprinted and the true values were $3 \times 10^{6}$ to $50 \times 10^{6}$ bacteria ( $\mathrm{g}$ dry soil $)^{-1}(\mathrm{~W}$. $\mathrm{H}$. Ko, personal communication).

Soil seems, therefore, to provide an unfavourable growth habitat for both fungi and bacteria. Some investigators (Gray \& Williams, 1971; Barber \& Lynch, 1977; Paul \& Voroney, 1980) have evaluated this in terms of the annual input of substrate to soil in the form of plant material, and suggested that in agricultural or forest soils the energy input may not be 
enough to satisfy even the maintenance energy requirement (Pirt, 1965) of the biomass. Heterotrophs seem able to grow only around plant roots or at the site of decomposing residues. This adds further indirect support to the nutrient deprivation hypothesis of microbiostasis.

In an earlier study (Lynch \& Panting, 1980) we investigated the variation in size of the biomass in some field soils. I have now used the same soils to investigate microbiostasis in terms of nutrient availability. To test for fungistasis, Penicillium citrinum was used with air-dried soils, as this had been shown to be a satisfactory indicator organism by Jackson (1958). For bacteriostasis, streptomycin-resistant Agrobacterium radiobacter was used with field soil (Ko \& Chow, 1977).

\section{METHODS}

Soils. The $\mathrm{pH}$ was estimated in a slurry with water (1 part soil to 2.5 parts water), the total soil organic carbon was measured in air-dried samples by oxidation with dichromate (Lynch \& Panting, 1980) and the moisture content was determined by drying in air at $80^{\circ} \mathrm{C}$ (Table 1). The clays are classified as Stagnogley (UK), Typic Haplaquept (USDA) and Eutric Gleysol (FAO/UNESCO). The silt loam is classified as Argillic Brown Earth (UK), Typic Hapladalf, in Alfisols (USDA) and Orthic Luvisol (FAO/UNESCO). The soils were taken from the field and either stored in large bins (capacity $50 \mathrm{l}$ ) or air-dried on trays. All soils were sieved to pass a $2 \mathrm{~mm}$ mesh. Gamma-irradiated ( $5 \mathrm{Mrad}$ ) soils were not used in experiments for at least 1 month after irradiation. Autoclaved $\left(121^{\circ} \mathrm{C}, 50 \mathrm{~min}\right)$ soils were used for experiments within a few hours. To estimate the soluble carbon released by soils, samples $(5 \mathrm{~g})$ were placed in test tubes containing distilled water $(5 \mathrm{ml})$, shaken by hand to ensure a uniform dispersion, centrifuged and the supernatant was passed through a filter $(0.22 \mu \mathrm{m})$. Samples were then injected into a Liquid Carbon Analyzer (model Toca 915-B, Beckmann-RIIC, Glenrothes, Scotland). Analyses were replicated.

Fungistasis. Bacteriological agar no. $1(2.5 \%, \mathrm{w} / \mathrm{v}$; Oxoid $)$ was prepared and portions $(10 \mathrm{ml})$ were added to Petri dishes $(85 \mathrm{~mm}$ diam.): discs were cut with a flamed cork borer. Penicillium citrinum IMI 68214 was grown on a slope of malt agar in a Universal bottle (capacity $28 \mathrm{ml}$ ), spores were harvested in sterile distilled water $(2 \mathrm{ml})$ and mycelial debris was removed by filtration through wire mesh.

Air-dried soil $(30 \mathrm{~g})$ was placed in a Petri dish $(85 \mathrm{~mm}$ diam.) and brought to $66 \%$ water-holding capacity. Four squares of Whatman no. 1 filter paper $(1 \times 1 \mathrm{~cm})$ were placed on the surface of the soil and an agar disc was placed on each square with a flamed scalpel. A sample $(10 \mu \mathrm{l})$ of the spore suspension was placed on the surface of each disc. Controls without soil were prepared in the same way except the agar discs and squares of filter paper were placed on Whatman no. 1 filter paper $(7 \mathrm{~cm} \mathrm{diam}$.) saturated with distilled water. Four replicates were used for each treatment. After inoculation the dishes were incubated at $25^{\circ} \mathrm{C}$ for $18 \mathrm{~h}$. The agar discs were then placed on a glass slide, a drop of water was added and a cover-slip was placed over it. Germinated and ungerminated spores were counted in four random fields of the microscope using an eyepiece grid. Spores were considered to have germinated if they had produced a germ tube of one spore diameter or more in length.

Bacteriostasis. A streptomycin-resistant isolate of Agrobacterium radiobacter NCIB 9042 was selected by preparing a thick suspension from a nutrient broth culture and spreading it on nutrient agar supplemented with streptomycin $\left(2 \mathrm{mg} \mathrm{ml}^{-1}\right)$. Resistant colonies were transferred to flask (325 ml capacity) cultures of nutrient broth $(100 \mathrm{ml})$ with streptomycin $\left(2 \mathrm{mg} \mathrm{ml}^{-1}\right)$ and grown for $2 \mathrm{~d}$ on a rotary shaker $\left(150 \mathrm{rev} \cdot \mathrm{min}^{-1}\right)$ at $20^{\circ} \mathrm{C}$. The bacterial suspension was centrifuged $(1500 \mathrm{~g}, 30 \mathrm{~min})$ and washed three times in sterile distilled water. A suspension was prepared in sterile distilled water $(100 \mathrm{ml})$ and samples were taken to determine the dry weight, the number of viable cells and the total number of cells.

The bacterial suspension $(1 \mathrm{ml})$ was mixed with soil $(10 \mathrm{~g})$ in a sterile beaker $(50 \mathrm{ml}$ capacity) using a flamed spatula. To estimate the number of viable cells present initially and after $24 \mathrm{~h}$, the soil was added to sterile distilled water $(100 \mathrm{ml})$, shaken vigorously for $5 \mathrm{~min}$ with a wrist-action shaker (Stuart Scientific Co., Croydon, Surrey) and serial dilutions were made. Viable cells developing into raised, smooth, glistening colonies were counted on nutrient agar supplemented with streptomycin.

Table 1. Soils used in the experiments

$\begin{array}{lcccc}\text { Soil type, location and series } & \mathrm{pH} & \begin{array}{c}\text { Soil organic } \\ \text { carbon } \\ (\%, \mathrm{w} / \mathrm{w})\end{array} & \overbrace{\text { Field soil }}^{\text {Moisture content }(\%, \mathrm{w} / \mathrm{w})} \\ \text { Compton Beauchamp, Denchworth } & 6 \cdot 2 & 4 \cdot 7 & 30 \cdot 6 & 4 \cdot 1 \\ \text { Northfield, Lawford } & 6 \cdot 5 & 2.9 & 31 \cdot 1 & 4.7 \\ \text { Oldfield, Lawford } & 6.4 & 2 \cdot 4 & 27 \cdot 3 & 5 \cdot 1 \\ \text { am, Englefield, Hamble } & 6.5 & 1.2 & 13 \cdot 7 & 1 \cdot 3\end{array}$

Clay, Compton Beauchamp, Denchworth

Clay, Northfield, Lawford

Clay, Oldfield, Lawford

Silt loam, Englefield, Hamble

$\mathrm{pH}$

$6 \cdot 5$

$6 \cdot 5$ oil organic carbon

4. 7

2.4 
Table 2. Organic carbon released into solution after soil treatment

\begin{tabular}{|c|c|c|c|c|c|c|}
\hline \multirow[b]{3}{*}{ Soil type and location } & \multicolumn{6}{|c|}{ Organic carbon in solution $\left[\mu \mathrm{g}(\mathrm{g} \text { dry soil })^{-1}\right]$} \\
\hline & \multicolumn{3}{|c|}{ Field soil } & \multicolumn{3}{|c|}{ Air-dried soil } \\
\hline & Untreated & Irradiated & Autoclaved & Untreated & Irradiated & Autoclaved \\
\hline Clay, Compton Beauchamp & 54 & 1213 & 1096 & 229 & 654 & 668 \\
\hline Clay, Northfield & 48 & 669 & 657 & 105 & 441 & 957 \\
\hline Clay, Oldfield & 51 & 118 & 537 & 128 & 528 & 494 \\
\hline Silt loam, Englefield & 43 & 468 & 260 & 88 & 203 & 187 \\
\hline
\end{tabular}

Table 3. Effect of rewetted air-dried soils on the germination of Penicillium citrinum spores

\begin{tabular}{lcccc}
\multicolumn{4}{c}{ Spore germination (\%) \pm standard error* } \\
\multicolumn{1}{c}{$\begin{array}{c}\text { Filter paper } \\
\text { Soil type and location }\end{array}$} & Untreated & Autoclaved & Irradiated \\
Clay, Compton Beauchamp & $25 \pm 1 \cdot 5$ & $12 \pm 0 \cdot 8$ & $85 \pm 1 \cdot 5$ & $69 \pm 3 \cdot 8$ \\
Clay, Northfield & $6 \pm 0 \cdot 5$ & $3 \pm 0 \cdot 7$ & $30 \pm 2 \cdot 1$ & $20 \pm 1 \cdot 2$ \\
Clay, Oldfield & $10 \pm 1 \cdot 0$ & $4 \pm 0 \cdot 6$ & $50 \pm 3 \cdot 0$ & $66 \pm 3 \cdot 1$ \\
Silt loam, Englefield & $11 \pm 1 \cdot 9$ & $7 \pm 0 \cdot 7$ & $55 \pm 2 \cdot 1$ & $67 \pm 2 \cdot 1$
\end{tabular}

* The means of 12 counts are recorded ( 11 degrees of freedom).

\section{RES ULTS}

The total carbon contents of the air-dried soils (Table 1) and the carbon released into solution (Table 2) were weakly correlated: the soil with the greatest amount of total carbon released the greatest amount of soluble carbon and that with the least total carbon released the least soluble carbon. The field soils each released similar amounts of carbon into solution (Table 2), even though their total carbon contents differed. Irradiation or autoclaving of both field and air-dried soils greatly increased the amount of carbon released into solution (Table 2). Treatment effects on the various soils probably differed because the form of organic matter present was different.

All soils were fungistatic to Penicillium citrinum (Table 3). Generally spore germination on untreated soil was half that in the control but that on autoclaved or irradiated soil was at least double that of the control. Percentage germinations are not comparable between soils since different spore suspensions were prepared for each and the inocula may have been in different physiological states.

Agrobacterium radiobacter did not grow in the untreated soils (Table 4), but its specific growth rate was $0.035 \mathrm{~h}^{-1}$ in each of the autoclaved soils, except the Compton Beauchamp clay when the rate was only $0.006 \mathrm{~h}^{-1}$ (Table 5). This rate was obtained in two replicate experiments. With this exception, the specific growth rates were similar to that described by Ko \& Chow (1977) for a soil from Hawaii. Bacterial growth in autoclaved Oldfield clay and Englefield silt loam soils was similar to that in the irradiated soils. There was no bacterial growth in Compton Beauchamp and Northfield clay irradiated soils, probably because of contamination of the soils by Penicillium spp. at least 1 week prior to inoculation of $A$. radiobacter.

The dry weight of $A$. radiobacter was found to be on average $1.7 \times 10^{-7} \mu \mathrm{g}$ per cell.

\section{DISCUSSION}

Drying a soil and rewetting it results in a flush in the mineralization of the soil humus to carbon dioxide (Birch, 1958, 1959, 1960) and an increase in microbial growth (Lund \& Goksøyr, 1980). This effect had been thought to be a consequence of the release of soluble 


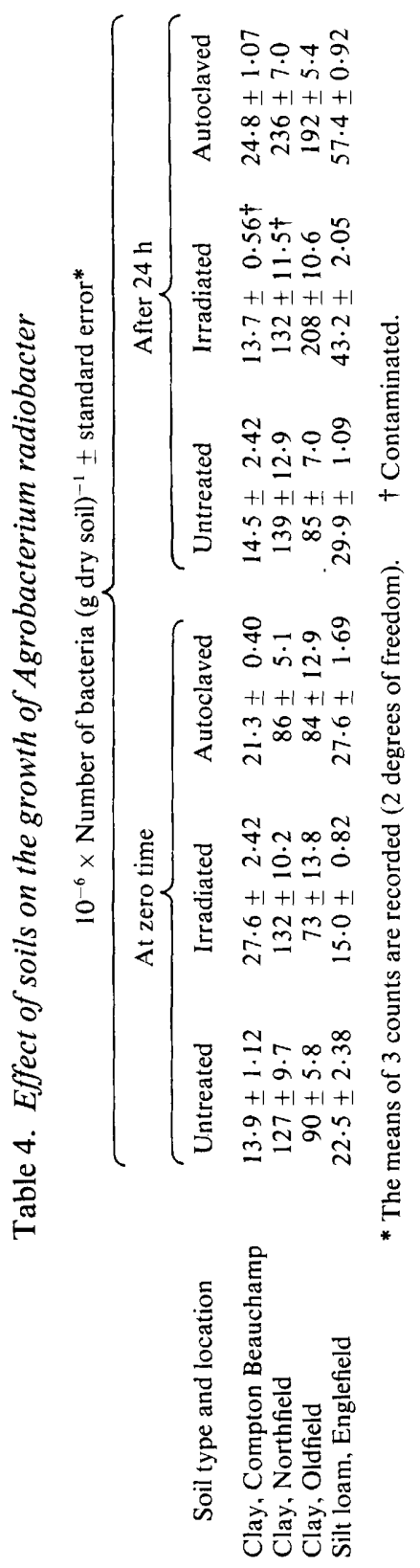


Table 5. Specific growth rates and doubling times of Agrobacterium radiobacter in autoclaved soils

\begin{tabular}{lcc}
\multicolumn{1}{c}{ Soil type and location } & Specific growth rate $\left(\mathrm{h}^{-1}\right)$ & Doubling time $(\mathrm{h})$ \\
Clay, Compton Beauchamp & 0.006 & $109 \cdot 3$ \\
Clay, Northfield & 0.042 & 16.4 \\
Clay, Oldfield & 0.035 & $20 \cdot 1$ \\
Silt loam, Englefield & 0.031 & 22.7 \\
Unspecified, Hawaii* & 0.029 & 23.6
\end{tabular}

* Modified data of Ko \& Chow (1977).

carbon for microbial growth, perhaps in part following cell death on drying; this can now be measured. Many experiments in soil microbiology use autoclaved or irradiated soils and besides other physical or chemical changes during these treatments they may provide a more nutrient-rich medium for microbial growth than do natural soils. The present results show that the soluble carbon content of field soil can be increased from about 50 to $1000 \mu \mathrm{g} \mathrm{C} \mathrm{(g} \mathrm{dry}$ soil $)^{-1}$. If this extra carbon were all utilized by micro-organisms with a growth yield of $0.5 \mathrm{~g}$ bacterial $\mathrm{C}$ (g substrate $\mathrm{C})^{-1}$, the soil biomass would increase by $475 \mu \mathrm{g} \mathrm{C}$ (g dry soil) ${ }^{-1}$. In the clay soils used, the biomass is commonly around $600 \mu \mathrm{g} \mathrm{C}$ (g dry soil) ${ }^{-1}$ (Lynch \& Panting, 1980), so treatment could potentially almost double the biomass. However, because of spatial inaccessibility and recalcitrance of some substrates, only a fraction of this carbon will be available to micro-organisms. The increase in biomass of $A$. radiobacter during the 24 $\mathrm{h}$ period can be calculated as follows: taking the dry weight carbon content of cells as $50 \%$, each cell contains $0.8 \times 10^{-7} \mu \mathrm{g} \mathrm{C}$. If the number of cells increases from $10^{8}$ to $2 \times 10^{8}$ (g dry soil $^{-1}$, the increase in biomass is $8 \mu \mathrm{g} \mathrm{C}$ (g dry soil) $^{-1}$. If $1000 \mu \mathrm{g} \mathrm{C}$ (g dry soil) ${ }^{-1}$ were available as before, then only a small fraction (less than $2 \%$ ) is utilized in microbial growth. Although $A$. radiobacter is probably still growing at the end of the $24 \mathrm{~h}$ period, it would probably not utilize all the carbon released by the treatment. However, the increase in soluble carbon and coincident release of stasis in treated soils indicate that carbon deprivation is likely to inhibit bacterial growth in field soils. No evidence was sought in the present study for inorganic nutrients being provided by the treatments; these could contribute to the effect.

In experiments with Nigerian soils (Jackson, 1958) using $P$. citrinum, the mean germination percentages were 82.8 (filter-paper control), 1.1 (untreated soil) and 78.4 (autoclaved soil). The large percentage germination in the control may be due to the high nutrient content of the Bacto-agar in comparison with the Bacteriological agar no. 1 used in the present experiments (Ho \& Ko, 1980); thus the results may be compatible. The decreased germination in untreated soil compared with the control could be caused by toxins or diffusion of nutrients from the agar discs (Ko \& Lockwood, 1967) and is much greater than that observed in the present experiments. The increased germination due to autoclaving in my experiments results from the release of soluble carbon by the treatment, but the carbon budget cannot be analysed in the same way as that for bacteria. However, from the evidence obtained in the present study, it seems that whereas soils show some toxicity to micro-organisms, the overriding explanation for microbiostasis is nutrient deprivation.

I am grateful to Miss Lynda M. Panting for excellent technical assistance, to Dr J. H. Slater for the provision of facilities for analysing soluble carbon, and to Professor T. R. G. Gray, Professor W. H. Ko and Dr R. M. Jackson for constructive comments.

\section{REFERENCES}

BARBER, D. A. \& LYNCH, J. M. (1977). Microbial growth in the rhizosphere. Soil Biology and Biochemistry 9, 305-308.
BIRCH, H. F. (1958). The effect of soil drying on humus decomposition and nitrogen availability. Plant and Soil 10, 9-31. 
Birch, H. F. (1959). Further observations on humus decomposition and nitrification. Plant and Soil 11, 262-286.

BIRCH, H. F. (1960). Nitrification in soils after different periods of dryness. Plant and Soil 12, 81-96.

Brown, M. E. (1973). Soil bacteriostasis limitation in growth of soil and rhizosphere bacteria. Canadian Journal of Microbiology 19, 195-199.

DAvis, R. D. (1975). Bacteriostasis in soils sterilized by gamma irradiation and in reinoculated sterilized soils. Canadian Journal of Microbiology 21, 481484.

Doвbs, C. G. \& Hinson, W. H. (1953). A widespread fungistasis in soils. Nature, London 172, 197-199.

DREW, M. C. \& LYNCH, J. M. (1980). Soil anaerobiosis micro-organisms and root function. Annual Review of Phytopathology 18, 37-67.

Gray, T. R. G. \& Williams, S. T. (1971). Microbial productivity in soil. Symposia of the Society for General Microbiology 21, 255-286.

Ho, W. C. \& Ko, W. H. (1980). Agarose medium for bioassay of antimicrobial substances. Phytopathology 70, 764-766.

JACKSON, R. M. (1958). An investigation of fungistasis in Nigerian soils. Journal of General Microbiology 18, 248-258.

Ko, W. H. \& CHow, F. K. (1977). Characteristics of bacteriostasis in natural soils. Journal of General Microbiology 102, 295-298.

Ko, W. H. \& HoRA, F. K. (1972). Identification of an $\mathrm{Al}$ ion as a soil fungitoxin. Soil Science 113, 42-45.
Ko, W. H. \& Lockwood, J. L. (1967). Soil fungistasis: relation to fungal spore nutrition. Phytopathology 57, 894-901.

Ko, W. H., Hora, F. K. \& Herlicksa, E. (1974). Isolation and identification of a volatile fungistatic substance from alkaline soils. Phytopathology 64, 1398-1400.

Lockwood, J. L. (1977). Fungistasis in soils. Biological Reviews 52, 1-43.

LuND, V. \& GoKsøYR, J. (1980). Effects of water fluctuations on microbial mass and activity in soil. Microbial Ecology 6, 115-123.

Lynch, J. M. \& Panting, L. M. (1980). Variations in the size of the soil biomass. Soil Biology and Biochemistry 12, 547-550.

Paul, E. A. \& Voroney, R. P. (1980). Nutrient and energy flows through soil microbial biomass. In Contemporary Microbial Ecology, pp. 215-237. Edited by D. C. Ellwood, J. N. Hedger, M. J. Latham, J. M. Lynch \& J. H. Slater. London: Academic Press.

PIRT, S. J. (1965). The maintenance energy of bacteria in growing cultures. Proceedings of the Royal Society B163, 224-231.

Schippers, B. \& PALM, L. C. (1973). Ammonia, a fungistatic volatile in chitin-amended soil. Netherlands Journal of Plant Pathology 79, 279281.

SMrth, A. M. \& CooK, R. J. (1975). Implications of ethylene production by bacteria for biological balance of soil. Nature, London 246, 311-313. 